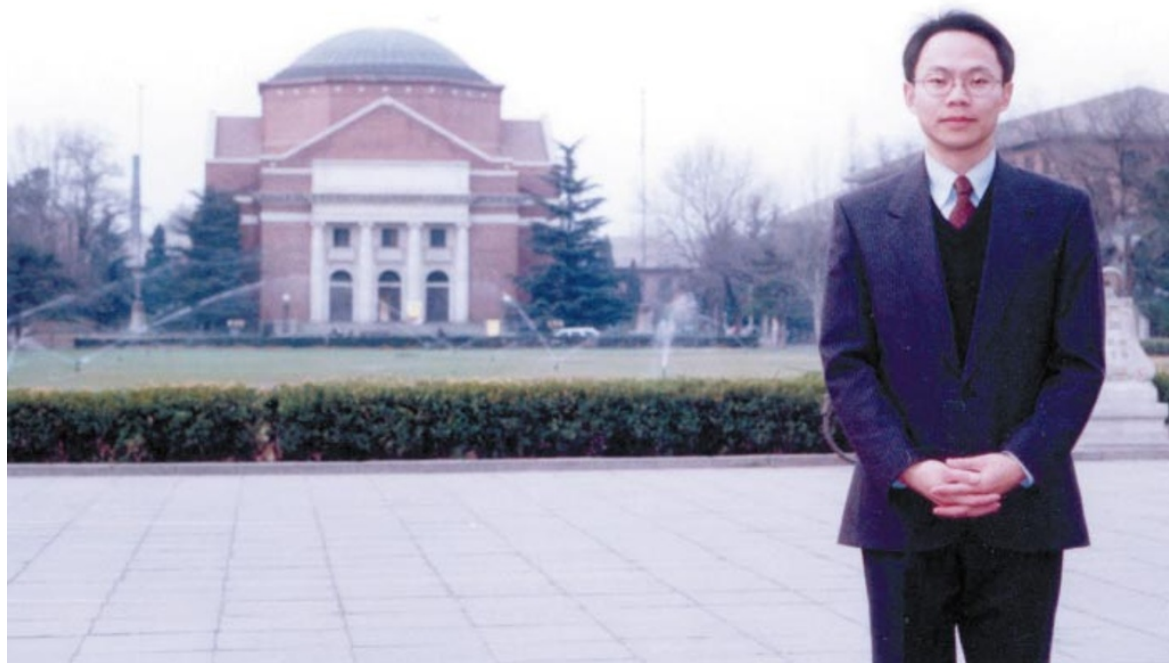

Cheng: forced to look outside China's borders for financial backing for his biochip venture business.

Taiwan is a pioneer in the region in the development of venture businesses. It has made a great success of its Hsinchu science park south of Taipei, which over the past decade and a half has drawn thousands of Taiwanese scientists and engineers back from the West. Dozens of successful startups in information technology have been established in the park, many of them linked to Silicon Valley in the United States, where more than one-third of the engineers and researchers are said to be of Taiwanese origin. A push into biotechnology that began at Hsinchu several years ago is also beginning to show some signs of success, which should be helped by substantial new government investments in research on agrobiotechnology, medical genomics and biopharmaceuticals (see box opposite).

Since moves to develop a market economy in China began in the 1980s, hundreds of start-up companies have been established by institutes of the Chinese Academy of Sciences and universities (Nature 378, 540-542; 1995). Most have been failures, but a significant few have been successful and have pumped much needed funds into their mother institutions.

One example is Beida Weiming Biotech Corporation, set up by Zhang-liang Chen, vice-president of Peking University, when he was a department chairman in 1992. The corporation's joint venture company, Kerxing Biopharmaceutical, established with a US company in 1994, now controls $60 \%$ of the market for interferon in China, and the corporation will shortly be listed on the Shanghai stock exchange, according to Chen.

But Chen sees many barriers to the successful establishment of start-up companies in China. There is a lack of creativity and originality in China's nascent biotechnology industry, and a tendency just to copy the
West's products. There is a need for greater protection of intellectual property rights, and venture capital is seriously lacking, particularly the long-term type required for biotech start-ups, says Chen.

Government regulations need to be eased, for example, to allow companies to donate money to universities and academic institutions free of tax. And the attitude of the academic community in China, which tends to look down on business activities, needs to change. Last but not least, Chen points to the dearth in China of scientists with entrepreneurial and Western business management skills.

But there is a growing realization in Chinese government circles and the research community that radical reforms are required for venture businesses to thrive. Tsinghua University in Beijing, one of the country's leading universities, at one time had 140 start-up companies, but this has now been slashed to about a dozen successful ones.

Similarly, the 123 institutes of the Chinese Academy of Sciences have more than 500 companies but, according to Yi Xun Yan, one of the four vice-presidents of the academy, only about a third are successful (many would say much less). The rest are a "big problem" for institute directors, says Yan, because it is difficult to close such companies, owing to social obligations to look after the employees.

Nevertheless, the academy has learnt "many important lessons" over the past decade, says Yan, and he is optimistic. He says the government is studying the need to create venture funds, and thinks there is growing awareness of the need to protect intellectual property rights.

But Yan, who established a successful thinfilm optics joint venture linked to the acade-

\title{
China's scientists tap offshore funds
}

Two entrepreneurial scientists at Tsinghua University in Beijing who have recently returned to China from the West provide examples of how venture businesses can be established in Asia even when the climate is far from ideal.

George Guo-Qiang Chen carried out microbiological research in Austria, Britain and Canada before returning to China in 1994. In collaboration with Daniel Shao, a financier in Hong Kong, and Thomas Wagner and other scientists at Ohio University in the United States, he has established Huagen Pharmaceutical, which plans to manufacture biopharmaceuticals based on recombinant peptides produced by transgenic Escherichia coli. Chen could not find investors in China because of legal hurdles and a "huge gap" in culture with the West, which is why he and his collaborators at Ohio turned to Shao.
Under a triangular arrangement, three people in Hong Kong will raise finance for the venture, four researchers at Ohio are developing recombinant organisms, an area pioneered by Wagner, while researchers at Tsinghua with experience in engineering will set up pilot production facilities. One Tsinghua scientist goes to Ohio each year to interact with the US collaborators.

Similarly, Jing Cheng (above), who has just returned to China to head a new biochip research and development centre at the university, is setting up a biochip venture business. Finance is expected to come from the United States, Taiwan, Hong Kong, and possibly mainland China itself.

Cheng started his career as an electrical engineer in a Chinese locomotive factory in 1983. He then went to Strathclyde University in Scotland to do his $\mathrm{PhD}$ and developed and patented a rapid DNA extractor in the department of pure and applied chemistry, before going to Aberdeen University's department of molecular and cell biology to develop capillary electrophoresis-based methods for mutation detection. He moved to the University of Pennsylvania School of Medicine to develop biochips under the sponsorship of PE Applied Biosystems, and then went to the US company Nanogen where he developed a portable bioelectronic chip for field use (see Nature Biotechnology 16, 541-546; 1998).

Cheng was attracted to Tsinghua by the opportunity to do interdisciplinary research spanning science and engineering, and he hopes Tsinghua will become the first university in China to enter high-tech ventures overseas and actively "borrow" foreign experience. 